\title{
PERILAKU KONSUMTIF KELUARGA PETANI PADI PASCA PANEN DI GAMPONG MATANG MANEH ACEH UTARA
}

\author{
M. Husen MR *), Maulina \\ ${ }^{*}$ Program Studi Sosiologi Universitas Malikussaleh, mmrhusen1975@gmail.com
}

\begin{abstract}
Consumptive behavior does not only affect modern urban society. The reality is that farmers who generally live in rural areas are also influenced by the consumptive culture. Post-harvest agricultural products are used as a momentum for shopping. The commodities purchased are not limited to necessities but also other needs that are the fulfillment of desires. This study focuses on farmers who do not own land in farming rice and have post-harvest consumptive behavior. Besides, this study also looks at the impact of consumer behavior on their lives. This research uses qualitative methods with a descriptive approach. The results showed that the motives of the families in Gampong Matang Maneh for post-harvest consumptive behavior were the availability of costs and the desire to behave consumptively. The impact of consumptive behavior on post-harvest farmers in Gampong Matang Maneh includes being unable to pay rent for land and difficulty meeting basic needs. Meanwhile, the efforts in meeting their daily needs are (a) involving family members to working, (b) and owes for basic needs.
\end{abstract}

ABSTRACT

Keywords: Consumptive Behavior, Rice Farmers, Post-Harvest

\begin{abstract}
ABSTRAK
Perilaku konsumtif tidak hanya menjangkiti masyarakat modern perkotaan. Realitasnya para petani yang umumnya hidup di wilayah pedesaan juga terpengaruh budaya konsumtif. Pasca panen hasil pertanian dijadikan momentum untuk berbelanja. Komoditas yang dibeli tidak terbatas pada kebutuhan pokok melainkan juga kebutuhan lain yang bersifat pemenuhan hasrat dan keinginan. Penelitian ini memfokuskan pada petani yang tidak memiliki lahan sendiri dalam bertani padi dan berperilaku konsumtif pasca panen. Selain itu, studi ini juga melihat dampak yang ditimbulkan dari perilaku konsumtif terhadap kehidupan keluarga petani. Penelitian ini menggunakan metode kualitatif dengan pendekatan deskriptif. Hasil penelitian menunjukkan bahwa motif keluarga petani di Gampong Matang Maneh berperilaku konsumtif pasca panen adalah tersedianya biaya dan keinginan berperilaku konsumtif. Adapun dampak perilaku konsumtif terhadap petani pasca panen di Gampong Matang Maneh diantaranya tidak sanggup membayar sewa tanah dan kesulitan memenuhi kebutuhan pokok. Sementara upaya yang dilakukan dalam memenuhi kebutuhan sehari-hari adalah (a) melibatkan anggota keluarga dalam bekerja, (b) dan mengutang kebutuhan pokok.
\end{abstract}

Kata Kunci: Perilaku Konsumtif, Petani Padi, Pasca Panen 


\section{PENDAHULUAN}

Pertanian merupakan mata pencaharian pokok sebagian besar masyarakat di pedesaan. Gampong Matang Maneh Kecamatan Tanah Jamboe Aye Kabupaten Aceh Utara adalah salah satu desa agraris tersebut. Berdasarkan observasi awal, masyarakat Gampong Matang Maneh sebagian besar bertani padi. Diantara mereka ada yang memiliki lahan sendiri, ada yang menyewa lahan untuk bertani, dan ada pula yang berprofesi sebagai buruh tani. Hal ini sesuai dengan klasifikasi Penny \& Ginting (1984) bahwa petani di Indonesia diantaranya petani pemilik, petani penyewa, petani penggarap, dan buruh tani.

Para petani menghasilkan pendapatan secara periodik yakni ketika masa panen tiba. Idealnya sebagian pendapatan dari menjual hasil panen ini disisihkan untuk keperluan bercocok tanam di periode selanjutnya. Sebab selama bercocok tanam petani membutuhkan banyak biaya seperti sewa tanah (bagi petani yang tak memiliki lahan sendiri), membeli bibit, pupuk, dan pestisida, biaya menanam dan memotong padi, serta biaya lainnya. Banyaknya biaya yang diperlukan untuk keperluan bercocok tanam di musim selanjutnya seharusnya mendorong para petani berhemat. Bahkan petani perlu menyediakan pula dana jaga-jaga guna mengantisipasi potensi gagal panen. Sementara sebagian pendapatan yang lain tentunya dipergunakan untuk memenuhi kebutuhan pokok keluarga. Disebabkan masa panen tidak terjadi dalam jangka waktu satu bulan, maka petani harus bijak dalam mengatur atau mengelola keuangan rumah tangga mereka.

Berdasarkan pengamatan, pendapatan petani pasca panen ternyata dialokasikan pula pada pemenuhan perilaku konsumtif seperti membeli handphone, sepeda motor, televisi, kulkas, lemari kaca, dan sebagainya. Pemenuhan kebutuhan sekunder dan tersier ini sebenarnya tidak menjadi masalah bila kebutuhan pokok dan modal bercocok tanam sudah terpenuhi. Tetapi sebaliknya yang terjadi adalah alokasi kebutuhan pokok dan modal bercocok tanam yang seharusnya disisihkan malah dipotong guna memenuhi hasrat konsumtif.

Perilaku konsumtif masyarakat petani tersebut berdampak bagi mereka seperti tidak sanggup membayar biaya sewa sehingga menyisakan utang kepada pemilik lahan dan tidak mampu memenuhi kebutuhan pokok sehari-hari secara wajar. Kehidupan masyarakat tampak jauh dari sejahtera. Berbagai upaya ekstra harus dilakukan dalam memenuhi kebutuhan hidup yang terus meningkat. Kaum perempuan pasca panen harus bekerja lagi secara serabutan. Begitu pun kaum lelaki harus bekerja sampingan dengan menjadi buruh bangunan, tukang ojek, dan sebagainya. Berdasarkan fenomena di atas penulis tertarik melakukan penelitian dengan judul Perilaku Konsumtif Petani Padi Pasca Panen (Studi di Gampong Matang Maneh Kecamatan Tanah Jamboe 
Aye Kabupaten Aceh Utara) guna menggali motif, dampak, dan pola adaptasi yang dilakukan dalam memenuhi hasrat konsumtif.

\section{Perilaku Konsumtif}

Pada dasarnya manusia bekerja mempunyai tujuan tertentu yaitu memenuhi kebutuhan. Kebutuhan tidak terlepas dari kehidupan sehari-hari. Kebutuhan manusia sangatlah bermacammacam seperti makanan, pakaian, rumah, pendidikan, dan kesehatan. Terdapat kebutuhankebutuhan manusia menurut intensitasnya. Kebutuhan menurut intensitas artinya kebutuhan yang didasarkan pada tingkat kepentingan, terdiri dari kebutuhan primer, kebutuhan sekunder, dan kebutuhan tersier (Ibrohim, 2017). Kebutuhan primer dapat diartikan sebagai kelompok kebutuhan utama atau kebutuhan pokok yang pertama harus dipenuhi untuk mempertahankan hidup. Secara umum, kebutuhan primer berupa pangan (makanan), sandang (pakaian), dan papan (tempat tinggal). Tanpa makanan, pakaian, dan kediaman maka manusia tidak dapat hidup karena dapat mati kelaparan, kedinginan, dan kepanasan. Kebutuhan sekunder dapat diartikan sebagai kebutuhan kedua yang harus dipenuhi setelah kebutuhan primer. Contoh kebutuhan sekunder dapat berupa meja, tas, sisir, kursi, lemari, sepatu, buku, kaos kaki, pensil, tempat tidur. Kebutuhan sekunder ini perlu dipenuhi dalam rangka mengaktualisasikan diri sebagai makhluk sosial yang berbudaya. Terakhir kebutuhan tersier. Kata tersier berasal dari kata ter-tius, yang artinya ketiga. Kebutuhan tersier juga disebut sebagai kebutuhan mewah atau lux.

Konsumsi merupakan penggunaan barang dan jasa untuk memenuhi kebutuhan hidup (Tambunan, 2010). Barang yang dikonsumsi akan habis atau mengalami penyusutan sedikit demi sedikit sehingga akhirnya tidak dapat digunakan lagi. Engel (dalam Mangkunegara, 2002) mengemukakan bahwa perilaku konsumsi ditandai oleh tindakan-tindakan individu yang secara langsung terlibat dalam usaha memperoleh dan menggunakan barang dan jasa ekonomis termasuk proses pengambilan keputusan yang mendahului dan menentukan tindakan-tindakan tersebut. Konsumsi adalah bagaimana aktor sosial dengan kebutuhan yang dimilikinya berhubungan dengan sesuatu (dalam hal ini material, barang simbolik, jasa atau pengalaman) yang dapat memuaskan mereka (Slater dalam Damsar \& Indrayani, 2009). Dengan demikian, tindakan konsumsi tidak hanya dipahami sebagai makan, minum, sandang dan papan saja tetapi juga harus dipahami dalam berbagai fenomena dan kenyataan lainnya (Rachel \& Rangkuty, 2020).

Konsumsi dalam perspektif sosiologi bukan sekedar pemenuhan kebutuhan fisik, melainkan justru yang lebih utama adalah pemenuhan kebutuhan sosial berupa status sosial yang tinggi dengan memiliki barang-barang tertentu atau mengonsumsi jasa mewah lainnya. Pada titik 
ini, orang rela mengeluarkan uang dalam jumlah besar, bahkan mungkin melebihi harga ekonominya demi memperoleh status sosial yang tinggi (Haryanto, 2011; Bakti, et al., 2020).

Sejauh ini studi tentang perilaku konsumtif keluarga petani pernah dilakukan oleh beberapa peneliti sebelumnya, antara lain Sunarto (2015), Siti (2016), Sudi \& Rini (2018), Lestari \& Muthali'in (2018), dan Utami \& Bashori (2020). Diantara studi yang sudah disebutkan sebelumnya belum ada studi konsumtivisme petani di wilayah Aceh. Lebih khusus lagi, studi ini berfokus pada kelompok petani padi yang memproduksi makanan pokok dimana harga pasaran beras sangat dijaga kenaikannya oleh pemerintah. Berbeda dengan studi sebelumnya yang berfokus pada kelompok petani komoditas ekspor seperti kopi, cengkeh, tembakau, dan kelapa sawit dengan potensi penghasilan yang relatif lebih besar sehingga mendorong perilaku konsumtif.

\section{METODE PENELITIAN}

Penelitian ini dilakukan di Gampong Matang Maneh Kecamatan Tanah Jamboe Aye Kabupaten Aceh Utara dengan menggunakan metode kualitatif. Maksud penulis yaitu mendeskripsikan penyebab masyarakat berperilaku konsumtif pasca panen dan upaya yang dilakukan oleh masyarakat dalam memenuhi kebutuhan pasca panen. Sumber data dalam penelitian ini yaitu: 1) data primer, adalah data-data yang diperoleh dari sumber asli yang memberi informasi langsung dalam penelitian, diperoleh dari hasil observasi dan wawancara dengan informan penelitian. 2) data sekunder, adalah data yang diperoleh dari sumber yang tidak langsung memberi informasi atau data (Haryono, 2003). Sumber data sekunder dalam penelitian ini diantaranya buku, artikel, koran, publikasi jurnal, dan karya ilmiah yang berhubungan dengan penelitian ini. Teknik

pengumpulan data yang digunakan yaitu: 1) observasi, digunakan untuk melihat dan mengamati secara langsung keadaan di lapangan agar peneliti memperoleh gambaran yang lebih luas tentang permasalahan yang diteliti (Basrowi \& Suwandi, 2008). Penelitian ini menggunakan observasi nonpartisipasi yaitu observer tidak terlibat langsung secara aktif dalam objek yang diteliti (Usman \& Akbar, 2009). 2) wawancara, dilakukan wawancara tak terstruktur. Penelitian ini menggunakan teknik analisis data menurut Miles \& Huberman (dalam Emzir, 2011). Ada tiga macam kegiatan dalam analisis data kualitatif yaitu: a) reduksi data, b) model data, dan c) penarikan kesimpulan.

\section{HASIL DAN PEMBAHASAN}

\section{Motif Masyarakat Berperilaku Konsumtif Pasca Panen}

Berdasarkan observasi, pada hari biasa di luar masa panen para petani menjalani kehidupan mereka secara apa adanya. Perilaku konsumtif petani justru baru muncul ketika masa panen tiba. 
Mereka mulai memborong kebutuhan yang sifatnya sekunder dan tersier. Hasil wawancara dengan Geuchiek Gampong Matang Maneh menjelaskan bahwa:

"Kebanyakan masyarakat di gampong saya ketika panen banyak membeli barang-barang yang tergolong mahal, ada membeli kereta baru dan bekas, ada membeli perabot, televisi, parabola, lemari, kulkas, dan sebagainya. Itu setiap musim panen pasti ada yang berbelanja. Tetapi kalau hari biasa tidak ada, bahkan jarang terlihat orang berbelanja banyak. Paling jika ada satu atau dua orang saja. Kalau ini semua masyarakat yang bertani pasti ada barang yang dibelikan ketika panen.” (Sufli Yani, Gampong Matang Maneh, 5 Oktober 2020).

Motif masyarakat di Gampong Matang Maneh berperilaku konsumtif pasca panen beraneka ragam. Salah satu motif utama yaitu tersedianya biaya untuk berperilaku konsumtif. Hal ini disebabkan pada momentum pasca panen para petani memiliki kelebihan uang, sedangkan pada hari biasa pendapatan petani hanya cukup untuk memenuhi kebutuhan sehari-hari. Sebagaimana dijelaskan oleh salah seorang warga masyarakat di gampong tersebut:

"Hanya ketika panen saja ada uang banyak. Kalau sudah panen sudah ada uang dari penjualan padi. Kalau tidak musim panen tidak ada uang banyak, paling hanya uang jualan kue saja yang dititipkan di warung. Uangnya cukuplah untuk jajan anak sekolah dan tidak ada yang lebih pun. Makanya ketika panen saja yang dapat menghasilkan banyak uang. Jadi bisa berbelanja. Kalau jualan kue tiap hari hanya dapat uang Rp 60.000 saja. Sudah cukup buat uang jajan anak Rp 10.000, uang bensin Rp 10.000, belanja bahan buat kue Rp 20.000. Ada sisa Rp 20.000 cukup beli ikan dan sayur. Jadi tidak ada lebih untuk disimpan." (Nurhalimah, Gampong Matang Maneh, 5 Oktober 2020).”

Dari hasil wawancara yang lain dengan ibu Zainabon dapat dipahami bahwa motif masyarakat di Gampong Matang Maneh berperilaku konsumtif pasca panen hampir sama dengan informan sebelumnya. Tersedianya uang dalam jumlah besar mendorong masyarakat membeli barang yang harganya relatif mahal. Sebab ketika tidak musim panen mereka tidak memperoleh pendapatan yang banyak, seperti diuatarakan:

"Ketika panen saja ada uang lebih dan bisa berbelanja barang yang harganya mahal. Kalau sehari-hari mana ada pendapatan yang banyak, paling pendapatan cukuplah membeli seragam, peralatan menulis dan buku belajar anak. Sebab saya tidak ada pekerjaan harian yang dapat menghasilkan uang. Pekerjaan saya hanya beternak ayam dan bebek. Seminggu sekali atau dua kali saja saya jual telur ayam dan bebek. Dari usaha itu ada uang, tetapi tidak cukup untuk disimpan karena banyak butuh biaya untuk kebutuhan sehari-hari. Makanya ketika panen ada uang banyak dari hasil jual padi, jadi bisa berbelanja." (Zainabon, Gampong Matang Maneh, 5 Oktober 2020).

Kedua informan di atas sudah lama berprofesi sebagai petani sawah. Namun mereka bukan petani pemilik lahan. Selama ini kedua informan tersebut menyewa lahan dari pemilik tanah. Hal rincinya disampaikan pada keterangan berikut:

34 | Jurnal Ilmu Sosial dan Ilmu Politik Malikussaleh (JSPM) Volume 2 Nomor 1 Tahun 2021 
"Saya tidak ada sawah, hanya sawah orang lain saya sewa. Besarnya sawah satu mah saja, dan sewa Rp 1.500.000 sekali panen. Ketika panen bayar sewanya. Jadi kemaren saya memperoleh hasil panen lima gunca, dan saya jual semua hasil panen dan mendapatkan uang Rp 6.500.000. Sebagian saya pergunakan untuk membeli kulkas harganya Rp 2.500.000. Setelah itu membeli peralatan dapur, seperti piring, gelas, panci, ember, blender, dan habiskan uang Rp 1.500.000. Selanjutnya, membeli pakaian saya dan anak sudah habis Rp 1.000.000. Selanjutnya, membeli parabola, karena anak minta dibeliin parabola, biar nampak banyak siaran televisi." (Nurhalimah, Gampong Matang Maneh, 5 Oktober 2020).

"Saya tidak ada lahan sawah. Tetapi saya ada lahan yang saya sewa ukurannya $1 \mathrm{mah}$. Saya sewa Rp 1.500.000 sekali panen. Dari hasil bertani tersebut ada memperoleh uang Rp 6.300.000 dari jualan padi. Tetapi uangnya sudah saya belikan lemari kaca supaya ada tempat untuk menyusun piring, gelas dan sebagainya. Harganya Rp 3.000.000. Selebihnya anak sudah minta dibelikan handphone, kalau tidak dibelikan marah karena temannya ada handphone. Beli handphone harganya Rp 1.500.000. Ada sisa uang lebih sudah beli kain baju dan jahit sendiri di rumah sudah habis uang Rp 500.000. Selanjutnya, ada beli kipas angin habiskan uang Rp 500.000. Ada sisa uang untuk membeli kebutuhan pokok." (Zainabon, Gampong Matang Maneh, 5 Oktober 2020).

Terkait dengan sewa-menyewa lahan, peneliti sudah mengkonfirmasi keterangan di atas dengan Geuchik Gampong Matang Maneh sebagaimana penjelasan berikut:

"Banyak masyarakat yang tidak memiliki lahan yang memilih sewa lahan supaya bisa bertani. Mereka sewa lahan kepada pemilik lahan di gampong seperti lahan Tgk $\mathrm{H}$. Zainuddin dan Haji Husein. Orang tersebut banyak lahan. Lahan disewa dalam jangka sekali panen dan setiap luas lahan berbeda-beda jumlah sewanya, misalnya kalau luas lahan 2 kupang itu sewanya Rp 500.000 dan luas lahan 1 mah sewanya Rp 1.500.000." (Sufli Yani, Gampong Matang Maneh, 10 Oktober 2020).

Meskipun tidak memiliki lahan sendiri, keluarga petani tersebut tetap memprioritaskan tindakan pembelian barang konsumtif. Pembelian barang yang dilakukan oleh keluarga petani bertujuan untuk memenuhi kebutuhan sekaligus keinginan. Komoditas yang dibeli memiliki nilaiguna atau kemanfaatan. Hasil wawancara dengan informan menjelaskan bahwa:

"Sebenarnya kalau lemari kaca dan kipas angin itu penting, sebab ada manfaatnya bagi saya... Sedangkan baju juga kepingin ada pakaian untuk pergi kemana-mana seperti pesta, sebab tidak mungkin memakai baju lama selalu. Sedangkan handphone saya beli karena sudah dipaksa oleh anak... Dari lebih itulah baru disisihkan untuk membeli kebutuhan pokok, seperti ikan, sayuran, gula, minyak, dan sebagainya." (Zainabon, Gampong Matang Maneh, 5 Oktober 2020).

Wawancara dengan informan lain dapat dipahami bahwa terdapat rasa senang dan kepuasan ketika berperilaku konsumtif pasca panen. Hal ini dikarenakan mereka sudah mampu membeli 
berbagai barang yang selama ini diinginkannya. Kemampuan membeli barang seringkali dijadikan ukuran keberhasilan atas kinerja yang bersangkutan sebagai petani.

Dari hasil wawancara dengan beberapa informan dapat dipahami bahwa motif masyarakat berperilaku konsumtif karena keinginan dari mereka sendiri. Para petani ingin membeli barang yang disukai, namun keterbatasan biaya membuat mereka tidak sanggup membeli barang selain mengandalkan pendapatan hasil panen. Hal ini dikarenakan mereka tidak memiliki pekerjaan sehari-hari yang menghasilkan banyak uang. Pendapatan mereka hanya cukup untuk memenuhi kebutuhan sehari-hari. Oleh sebab itu, hanya ketika panen padi mereka dapat menghasilkan uang sehingga mereka memanfaatkan kesempatan tersebut untuk membeli barang yang relatif mahal. Salah seorang masyarakat di Gampong Matang Maneh menjelaskan bahwa:

“... melihat orang membawa kereta baru membuat saya ingin juga membeli kereta seperti mereka. Selain itu, kereta sudah menjadi kebutuhan untuk pergi kemana-mana seperti antar anak ke sekolah, pergi ke pasar, atau bepergian tempat saudara, pesta maupun orang meninggal, ketimbang naik ojek yang banyak menghabiskan biaya." (Sulaiman, Gampong Matang Maneh, 7 Oktober 2020).

\section{Lebih lanjut Bapak Sulaiman menceritakan:}

"Hanya ketika panen saja ada uang. Kemaren saya memperoleh pendapatan Rp 6.000.000. Selanjutnya, saya ada juga bekerja prontok, mengumpulkan gabah, dan mengangkut padi. Sehari-hari ada dapat uang minimal Rp 300.000 hingga Rp 400.000. Ada sisa uang saya simpan bekerja di sawah selama sebulan penuh yaitu Rp 7.000.000. Tidak hanya di sawah sendiri saya kerja, namun sawah di gampong sekitar juga ada. Jadi ada memperoleh pendapatan Rp 13.000.000. Uang tersebut sudah saya beli kereta matic Beat bekas. Alhamdulillah sekarang sudah ada kereta untuk pergi kemana-mana." (Sulaiman, Gampong Matang Maneh, 7 Oktober 2020).

Sama seperti petani lain pada umumnya, Bapak Sulaiman tidak memiliki pekerjaan tetap selain ke ladang. Dalam mencari tambahan penghasilan, informan tersebut bekerja sebagai kuli bangunan jika diajak oleh temannya. Sementara di waktu senggang ia berkebun dengan menanam pisang, tebu, jagung, terong, pepaya, dan ubi dengan harapan hasilnya dapat dijual ke pasar dan dikonsumsi oleh keluarganya.

Sementara itu, hasil wawancara dengan warga masyarakat lain di Gampong Matang Maneh menjelaskan bahwa faktor sosial memberikan andil dalam peningkatan hasrat konsumsi masyarakat, sebagaimana disampaikan:

"Setelah panen kemaren, saya ada membeli prabot kursi dan meja tempat duduk. Saya membelinya karena suka dan kepingin punya prabot di rumah seperti rumah tetangga saya cantik prabotnya. Kalau ada prabot di rumah nampak mewah, sebab ketika ada tamu ada tempat duduk. Lagian tidak mungkinpun selalu menyiapkan tikar untuk duduk tamu, 
apalagi tikar banyak yang sudah tidak bagus lagi dan malu untuk dipakai untuk tamu." (Fitriani, Gampong Matang Maneh, 7 Oktober 2020).

Informan lebih jauh menjelaskan bahwa sebagian masyarakat yang berperilaku konsumtif pasca panen tidak memiliki lahan pertanian milik sendiri, melainkan lahan yang disewakan dari pemilik lahan. Biasanya sewa tanah dengan ukuran satu mah adalah Rp 1.500.000. Dengan adanya sawah yang disewakan, masyarakat dapat bertani padi dan memperoleh pendapatan dari hasil panen padi. Selanjutnya, sebagian masyarakat juga bekerja sebagai buruh tani, seperti kaum ibu bekerja memotong padi dan memperoleh pendapatan per hari Rp 80.000. Mereka tidak hanya bekerja sebagai buruh tani di gampong sendiri, melainkan di gampong sekitar. Dari pekerjaan tersebut dapat memperoleh pendapatan untuk sebagian ditabung. Informan sendiri menabung uang Rp 1.000.000 selama bekerja satu bulan sebagai buruh tani di musim panen. Sementara sebagian besar pendapatan diperoleh dari penjualan hasil panen padi yang dikelola sendiri. Jika ada lahan satu mah dapat memperoleh hasil panen padi sebanyak 5 gunca. Dari hasil tersebut sebanyak 4 gunca dijual dan memperoleh pendapatan Rp 5.000.000, sedangkan sisanya yaitu 1 gunca (sekitar 5 atau 6 karung) disimpan untuk dijadikan beras konsumsi rumah tangga sehari-hari.

Pasca panen padi daya beli petani mengalami peningkatan drastis. Pada saat itu petani memiliki kemampuan untuk mewujudkan hasrat konsumtifnya. Disadari bahwa masyarakat petani di Gampong Matang Maneh melakukan proses konsumsi komoditas berdasarkan pertimbangan nilai-guna. Idealnya setiap tindakan konsumsi harus dilakukan atas dasar prinsip ekonomi dan prioritas kebutuhan. Hal ini disebabkan kebutuhan itu tidak terbatas, sedangkan pendapatan adalah sangat terbatas (Ahmadi, 2003). Tetapi rasionalitas ekonomi masyarakat petani itu sangat relatif. Masyarakat di Gampong Matang Maneh tetap berperilaku konsumtif pada momentum tertentu dengan membeli berbagai jenis barang. Perilaku tersebut didasarkan pada keinginan masyarakat untuk berperilaku demikian. Mereka menikmati barang yang dibelanjakannya sehingga menimbulkan rasa puas, senang, dan bahagia karena sudah memiliki barang yang diinginkannya. Keinginan berperilaku konsumtif juga dipengaruhi oleh lingkungan tetangga.

Sebagaimana dijelaskan oleh Sumartono (2002: 63) bahwa faktor-faktor yang mempengaruhi seseorang berperilaku konsumtif terdiri dari faktor internal dan faktor eksternal. Faktor internal pada kasus ini seperti adanya keinginan masyarakat membeli barang yang disukainya sehingga memiliki kepuasan setelah membelanjakan barang tersebut. Sedangkan faktor eksternal yaitu dorongan mengonsumsi karena tetangga sudah terlebih dahulu melakukannya. 
Ditambah lagi dengan serbuan iklan di televisi dan media sosial yang juga turut memberikan pengaruh signifikan.

\section{Dampak Perilaku Konsumtif terhadap Kehidupan Petani Pasca Panen}

Perilaku konsumtif masyarakat petani di Gampong Matang Maneh membawa dampak yang kurang baik terhadap kehidupan mereka. Salah satu dampak terbesar yang dialami oleh keluarga petani yaitu ketidaksanggupan mereka membayar sewa lahan karena uang sewa yang sesuai perjanjian seharusnya diberikan pasca panen sudah terlanjur dibelanjakan. Hal ini berdampak pada kesulitan para petani tersebut untuk memperoleh kepercayaan (trust) dari pemilik lahan pada musim tanam yang akan datang. Dalam kondisi ini, timbul perasaan malu kepada pemilik lahan karena harus menunda pembayaran pada panen musim depan. Hal ini dialami oleh salah seorang informan berikut:

"Dampaknya yaitu tidak sanggup membayar sewa tanah. Sebab sudah ada kesepakatan dengan pemilik lahan bayar sewa setelah panen dengan harga Rp 1.500.000. Alasan tidak sanggup bayar karena tidak ada uang lagi, sebab sudah berbelanja kemaren ketika panen... Akibat tidak membayar sewa, pertama merasa malu dengan pemilik lahan karena tidak tepati janji. Walaupun demikian tetap harus membayar. Hanya saja menunda membayar sewa. Makanya saya jumpain terus pemilik lahan dan menjelaskan apa adanya, meminta maaf tidak bisa membayar sewa padi, dan meminta untuk membayar sekalian pada hasil panen bertani musim ke depan, dengan jumlah bayar dua kali musim bertani yaitu Rp 3.000.000.” (Nurhalimah, Gampong Matang Maneh, 10 Oktober 2020).

Informan di atas masih beruntung karena pemilik lahan berbaik hati memaklumi perbuatannya dan memberinya kesempatan kedua. Tetapi beberapa petani mengalami peristiwa yang tidak diharapkan. Wanprestasi perjanjian dengan pemilik lahan ini berdampak signifikan. Beberapa petani mengalami kesulitan ekonomi karena perilaku mereka sendiri yang merusak modal sosial yang selama ini sudah terbina.

Beberapa pemilik lahan memang memberikan pemakluman terhadap para petani yang menggarap lahan mereka. Hasil wawancara dengan salah seorang pemilik lahan menjelaskan:

“Ada juga masyarakat yang menyewa lahan sawah saya tidak sanggup membayar karena sudah habis uang untuk hal lainnya. Saya paham juga mereka orang miskin dan perlu uang untuk kebutuhan keluarganya. Bagi saya jika tidak sanggup membayar sewa bulan ini dan membayar bulan depan tidak masalah. Asalkan ada bayar, kecuali tidak bayar bulan depan. Itu mungkin membuat saya kecewa, sebab saya membutuhkan uang. Selain itu, mereka yang sewa lahan saya bukan sekali pun, ada yang sudah sewa 6 kali musim bertani. Alhamdulillah mereka tepati janji semua, jadi saya tidak takut jika musim ini ada yang tidak bayar sewa.” (H. Zainuddin, Gampong Matang Maneh, 10 Oktober 2020). 
Begitu pula hasil wawancara dengan Bapak H. Husen menjelaskan bahwa:

"Ada juga masyarakat yang tidak sanggup membayar sewa karena sudah dipakai untuk kebutuhan lainnya. Tetapi mereka tetap membayarnya, ada yang minta bayar waktu panen selanjutnya, dan ada juga minta bayar cicil. Saya izinkan asalkan mereka mau membayar. Sampai saat ini masyarakat semua bayar sewa, walaupun ada yang nunggak itu hal biasa." (H. Husen, Gampong Matang Maneh, 10 Oktober 2020).

Pemaparan di atas diamini oleh Ibu Aminah. Menurut informan, pemilik lahan memberikan kelonggaran kepada dirinya untuk membayar uang sewa tanah dengan memberikan cicilan, seperti dikatakan:

"Saya sudah meminta maaf kepada pemilik lahan untuk tidak bisa membayar sewa hasil panen padi tahun ini karena hasil panen sudah saya pergunakan untuk kebutuhan lain. Namun pemilik lahan tidak marah di depan saya, dia hanya bilang berapa yang ada bisa kasih terus. Alhamdulillah saya cicil selama dua bulan, akhirnya lunas juga. Tetapi pemilik lahan tetap kasih untuk menyewa tanahnya. Walaupun bayar cicil." (Aminah, Gampong Matang Maneh, 10 Oktober 2020).

Selain merusak kadar perjanjian, konsumtivisme yang dialami masyarakat petani juga berdampak pada kesulitan yang mereka alami dalam memenuhi kebutuhan sehari-hari. Ironisnya, beberapa petani padi itu justru terpaksa membeli beras guna memenuhi makanan pokok mereka, seperti dijelaskan oleh Ibu Zainabon:

"Setelah menjual padi, saya mengalami kesusahan sebab harus membeli beras. Harga beras mahal. Satu karung ukuran $15 \mathrm{Kg}$ sekarang paling murah yaitu Rp 150.000. Sebab tidak ada padi lagi karena sudah saya jual, terpaksa harus membeli beras." (Zainabon, Gampong Matang Maneh, 11 Oktober 2020).

Masyarakat telah menjual hasil panen padi untuk memenuhi hasrat konsumtif sehingga tidak ada padi yang dikonsumsi untuk keluarga sendiri membuat masyarakat harus membeli beras. Namun harga beras di pasaran tergolong mahal bagi kebanyakan dari mereka. Adapun harga beras paling murah sekitar Rp 150.000 karena sudah berada di dalam kuasa pedagang grosir dan eceran. Hasil wawancara dengan Ibu Zainabon dapat dipahami bahwa:

"Hal yang membuat saya susah sekarang yaitu uang. Pendapatan saya tidak selalu ada setiap hari. Saya kerjaannya setiap hari yaitu beternak ayam dan bebek. Jadi pendapatan saya dari hasil penjualan telur. Biasanya saya jual per minggu sekali. Dalam seminggu ada dapat uang Rp 200.000 dari jualan telur ayam dan bebek. Sudah cukuplah buat uang jajan anak sekolah dan bensin keretanya. Namun masalahnya ketika suami tidak ada pekerjaan sehingga tidak ada uang untuk membeli beras. Selama ini kebutuhan keluarga saya bergantung pada suami. Namun suami tidak ada pekerjaan tetap, apa yang ada dikerjakan seperti tukang ojek sesekali, kerja buruh bangunan, dan sesekali bertani. Di saat ada kerja ada uang, namun saat tidak ada kerja tidak ada uang. Jadi susah untuk membeli kebutuhan 
pokok. Uang dari pendapatan saya tidak cukup untuk membeli beras.” (Zainabon, Gampong Matang Maneh, 11 Oktober 2020).

Hal serupa juga diungkapkan oleh Ibu Nurjannah, salah seorang warga masyarakat di Gampong Matang Maneh sebagaimana keterangan berikut:

"Ketika panen kemarin, saya ada menyimpan padi hanya 4 karung dan lainnya saya jual. Cukuplah dikonsumsi selama 4 bulan. Namun sekarang tidak ada padi lagi sudah habis, dan saya pun susah sebab uang pun tidak selalu ada. Suami saya bekerja di grosir, dan uangnya tidak banyak. Tidak cukup pun untuk membeli beras, sebab banyak kebutuhan lainnya yang harus dipenuhi, seperti kebutuhan anak sekolah. Paling sekarang hanya bisa meminta padi dulu sama orang tua saya, sebab orang tua saya ada bertani tetapi padinya tidak dijual semua. Jadi minta bantu sama orang tua." (Nurjannah, Gampong Matang Maneh, 11 Oktober 2020).

\section{Upaya Keluarga Petani Memenuhi Kebutuhan Pasca Panen}

a. Melibatkan Anggota Keluarga dalam Bekerja

Kesulitan yang dihadapi oleh keluarga petani pasca panen memunculkan pola adaptasi. Salah satu upaya yang dilakukan adalah melibatkan sumber daya manusia di dalam rumah tangga. Alhasil kerapkali dijumpai istri dan anak-anak petani turut serta membantu perekonomian keluarga. Hal itu sebagaimana disampaikan oleh informan:

"Kalau berharap dari upah saya kerja memang tidak cukup, alhamdulillah ada dibantu istri bekerja sehingga ada lah pemasukan tambahan yang dapat memenuhi kebutuhan keluarga. Pekerjaan istri saya ketika musim bertani bekerja menanam padi dan ketika musim panen bekerja memotong padi.... Ketika panen padi, istri bekerja memotong padi dan saya kerja prontok, mengumpulkan gabah, dan mengangkut padi. Di saat panenlah banyak dapat uang. Kalau saya sehari ada dapat sampai Rp 300.000 dan istri saya hanya dapat Rp 80.000 dari memotong padi. Alhamdulillah cukuplah untuk kebutuhan sehari-hari. Dari hasil pendapatan tersebut saya tabung, nanti dipergunakan untuk membeli sesuatu atau membayar utang... Selama istri bekerja terutama ketika musim bertani sudah sangat membantu saya, terutama ada biaya anak sekolah setiap hari..." (Hanif, Gampong Matang Maneh, 14 Oktober 2020).

Semenjak adanya keterlibatan istri yang bekerja, perekonomian keluarga petani di Gampong Matang Maneh sangat terbantu terutama dalam memenuhi kebutuhan pendidikan anak diantaranya untuk uang saku dan peralatan menulis. Sementara suami mencari penghasilan tambahan lain dari aktivitas berkebun, seperti diungkapkan informan:

"Kalau berkebun mana ada banyak uang paling sekali panen itu selama empat bulan misalnya ada dapat uang paling banyak Rp 2.000.000. Itu ada yang penjualan sekalian seperti pepaya, ubi, dan terong. Tapi ada juga jual per buah seperti pisang, jika sudah kuning langsung jual, dan begitu juga tebu jika ada yang minta beli per batang Rp 7000 saya jual terus. Kalau pisang satu tangkai itu harganya Rp 25.000 hingga Rp 30.000. Makanya kalau 
dijual semua ada lah harga seperti yang saya perhitungkan tadi. Sebab sebagian hasil kebun dikonsumsi untuk sendiri juga, seperti pisang, ubi buat kue. Pepaya dimakan, dan terong dibuat sayur..." (Hanif, Gampong Matang Maneh, 14 Oktober 2020).

Senada dengan keluarga Bapak Hanif, keluarga Bapak Sulaiman juga terpaksa melibatkan istri bekerja mencari tambahan penghasilan melalui usaha mikro. Bahkan anak-anak juga membantu perekonomian keluarga, seperti dikatakan:

"Alhamdulillah sekarang sudah ada usaha istri. Istri sudah berjualan gorengan dan mie Aceh dan sehari ada dapat uang Rp 70.000 hingga Rp 100.000. Cukuplah untuk kebutuhan sehari-hari. Selain itu, anak saya juga ada yang sudah dewasa dan bekerja di Perabot Panton Labu. Ada dibantu dari dia sedikit, ketika tidak ada uang dikasih uang misalnya, dikasih Rp 200.000. Cukuplah untuk uang jajan sekolah adiknya." (Sulaiman, Gampong Matang Maneh, 14 Oktober 2020).

Pelibatan anggota keluarga dalam membantu perekonomian juga dilakukan oleh keluarga Bapak Razali dan Bapak Mukhlis. Keluarga Bapak Razali melibatkan istri bekerja seperti membuat kue dan nasi gurih bungkus yang nantinya dititipkan di warung untuk dijual. Pendapatan yang diperoleh dari penjualan nasi bungkus yaitu Rp 100.000, dan pendapatan dari penjualan kue Rp 60.000. Dari usaha tersebut sehari dapat memperoleh pendapatan Rp 160.000. Setelah memotong biaya modal Rp 70.000, dan sisanya Rp 90.000 dipergunakan untuk membiayai kebutuhan keluarga. Dengan adanya usaha istri dapat membantu memenuhi kebutuhan keluarga. Sementara pada keluarga Bapak Mukhlis, sebagian anggota keluarga seperti anak sudah mampu bekerja dan mencari uang sendiri seperti bekerja bengkel dan grosir. Setiap harinya mereka membantu keluarga

dengan memberikan uang sebesar Rp 40.000. Uang tersebut dapat membantu membeli beras, sedangkan pendapatan ayahnya dipergunakan untuk kebutuhan lainnya.

\section{b. Mengutang Kebutuhan Pokok}

Pola adaptasi selanjutnya yang dilakukan oleh keluarga petani padi di Gampong Matang Maneh yaitu mengutang kebutuhan pokok. Hal ini sebagai dampak perilaku konsumtif pasca panen, sebagaimana yang dijelaskan oleh Bapak Ishak:

"Setelah menjual hasil panen padi, sudah sedikit tersisa padi, hanya 3 karung disimpan untuk makan. Namun hanya bertahan 1 bulan saja tanpa harus beli beras. Setelah itu, saya mulai kesusahan karena harus membeli beras, dan pekerjaan tidak rutin ada dan tidak selalu ada uang.... Saya mengutang padi 1 karung kepada adik atau abang saya di gampong juga, dan membayarnya ketika panen. Kalau mengutang padi lebih berkah, sebab 1 karung itu setelah digiling menjadi beras kadang sampai $40 \mathrm{Kg}$, ketimbang beli di pasar ukuran beras 15 kg harganya sampai Rp 160.000.” (Ishak, Gampong Matang Maneh, 15 Oktober 2020). 
Lain lagi dengan keluarga Bapak Ismail dan Bapak Hanif, utang kebutuhan pokok diperoleh dari tetangga dan temannya di Gampong Matang Maneh, seperti diceritakan:

“Akibat menjual padi, saya menjadi kesusahan untuk membeli beras... di pasar harga beras mahal dan uangpun tidak selalu ada sebab tidak ada kerjaan tetap. Terpaksa saya harus mengutang padi kepada tetangga samping rumah. Mengutang padi ukuran 3 tem, dan bayarnya juga 3 tem ketika panen. Tetanggapun mau membantu. Tetapi kalau ada uang saya tetap beli beras, biar tidak banyak mengutang." (Ismail, Gampong Matang Maneh, 15 Oktober 2020).

"Saya ada mengutang beras sama teman saya yang berjualan, mengutang gula, minyak, dan sebagainya. Namun tidak banyak saya mengutang, paling banyak Rp 1.000.000. Nanti ketika ada uang saya bayar cicil, setelah lunas baru saya mengutang kembali." (Hanif, Gampong Matang Maneh, 15 Oktober 2020).

Masyarakat Gampong Matang Maneh bekerja demi memperoleh pendapatan supaya dapat memenuhi kebutuhannya. Permasalahannya masyarakat berperilaku konsumtif pasca panen dengan mendahulukan pemenuhan kebutuhan sekunder ketimbang kebutuhan primer. Akhirnya pemenuhan kebutuhan sekunder berdampak pada pemenuhan kebutuhan primer.

Upaya yang dilakukan oleh masyarakat di Gampong Matang Maneh dalam memenuhi hasrat konsumtif melibatkan strategi aktif, strategi pasif, dan strategi jaringan (Suharto, 2009). Strategi aktif seperti melibatkan anggota keluarga dalam membantu meningkatkan pendapatan keluarga. Artinya mengoptimalkan segala potensi anggota keluarga untuk melakukan aktivitasnya dan melakukan pekerjaan sampingan. Selanjutnya, strategi pasif dilakukan dengan menekan pengeluaran untuk konsumsi pokok. Upaya lainnya yaitu mengutang padi kepada saudara kandung, kerabat, dan tetangga. Upaya tersebut termasuk dalam strategi jaringan, yaitu strategi untuk menjalin relasi baik formal maupun informal dengan lingkungan sosialnya sehingga dapat membantu mereka dalam memenuhi kebutuhan keluarga.

Berdasarkan hasil penelitian di atas, penulis menggunakan teori aksi perspektif Parsons untuk menganalisis temuan di lapangan dengan menggunakan konsep perilaku voluntaristik. Konsep ini mengandung pengertian kemampuan individu menentukan cara dan alat dari sejumlah alternatif yang tersedia dalam rangka mencapai tujuan. Individu yang memiliki tujuan disebut sebagai aktor. Tujuan merupakan keseluruhan keadaan konkret di masa depan yang diharapkan, sejauh relevan dengan kerangka acuan tindakan. Berdasarkan konsep ini, maka aksi masyarakat yang berperilaku konsumtif pasca panen diarahkan untuk mencapai tujuan, seperti ingin memiliki barang yang disukai dan dianggap dibutuhkan seperti sepeda motor, handphone, perabot rumah tangga, lemari kaca, kulkas, televisi, parabola, dan sebagainya. Namun permasalahannya adalah 
keterbatasan biaya yang dimiliki karena pekerjaan tidak tetap sehingga pendapatannya tidak tetap dan pendapatannya terbatas untuk memenuhi kebutuhan sehari-hari. Masyarakat menentukan cara dan alat yang tersedia seperti menyewa lahan pertanian padi dan hasil panen diperjualkan sehingga memperoleh pendapatan. Dari pendapatan tersebutlah masyarakat mempergunakannya untuk memenuhi hasrat konsumtif dengan membeli barang yang disukai.

Permasalahan yang dihadapi oleh masyarakat setelah berperilaku konsumtif adalah tidak memiliki biaya karena sudah dipergunakan membeli berbagai barang sehingga tidak mampu membayar sewa lahan yang seharusnya dibayar pasca panen sebagaimana kesepakatan dengan pemilik lahan. Selain itu, perilaku masyarakat yang menjual hasil panen padi sehingga padi yang disimpan sangat sedikit dan tidak cukup untuk memenuhi kebutuhan terutama beras. Hal ini mengakibatkan masyarakat harus membeli beras.

Permasalahan yang dihadapi adalah sebagian masyarakat yang memiliki pendapatan sedikit dan sebagian tidak ada pekerjaan tetap sehingga pendapatan yang diperoleh tidak mencukupi untuk memenuhi kebutuhan karena harus membeli beras yang harganya relatif lebih mahal. Oleh sebab itu, masyarakat tetap berusaha untuk memenuhi kebutuhannya dengan menentukan berbagai cara dan alat yang tersedia, seperti mengutang padi kepada saudara kandung dan tetangga. Ketika panen tiba mereka membayarnya juga dengan ukuran yang sama. Selanjutnya, masyarakat mengutang uang kepada kerabat agar dapat memenuhi kebutuhannya, dan mengutang berbagai barang kebutuhan pokok kepada temannya yang berjualan di pasar.

Selain berutang, masyarakat juga meningkatkan pendapatan keluarga dengan melibatkan anggota keluarga dalam bekerja. Seperti sebagian istri harus bekerja untuk membantu suami dalam memenuhi kebutuhan keluarga dengan bekerja sebagai buruh tani, berjualan kue, nasi bungkus, dan beternak ayam dan bebek. Selanjutnya, sebagian keluarga tersebut melibatkan anak yang sudah mampu bekerja dalam membantu memenuhi kebutuhan keluarga, seperti sebagian anak bekerja di toko prabot, keude grosir, dan bengkel. Pendapatan anak sebagian diberikan kepada orang tua untuk membantu memenuhi kebutuhan keluarga.

Orientasi motivasi pada teori aksi terdapat tiga komponen yang menyumbang tenaga yang digunakan untuk aksi, yaitu kognitif, katektik (penerimaan/penolakan terhadap objek), dan evaluatif. Dilihat dari kognitif, masyarakat di Gampong Matang Maneh berperilaku konsumtif pasca panen dikarenakan mereka mendefinisikan suatu situasi berdasarkan kepentingannya, seperti mendefinisikan pasca panen masyarakat dapat memperoleh pendapatan lebih banyak. Dengan memiliki pendapatan lebih banyak terdorong berperilaku konsumtif dengan membeli barang yang disukai. Namun ketika tidak musim bertani, masyarakat tidak berperilaku konsumtif karena 43 | Jurnal Ilmu Sosial dan Ilmu Politik Malikussaleh (JSPM) Volume 2 Nomor 1 Tahun 2021 
pendapatannya yang sedikit sehingga tidak mampu bahkan sekedar untuk memenuhi kebutuhan keluarga, apalagi untuk membeli berbagai barang yang disukainya.

Dilihat dari katektik, hal ini berhubungan dengan kepuasan atau perasaan atau tanggapan atas objek. Masyarakat di gampong tersebut berperilaku konsumtif pasca panen karena didorong oleh keinginan untuk memiliki barang yang disukainya. Apabila telah memiliki barang yang disukainya tentunya akan membawa perasaan senang dan puas sebab sudah tercapai tujuannya.

Dilihat dari evaluatif, dimana masyarakat di gampong tersebut yang berperilaku konsumtif yang sudah membawa dampak seperti menyisihkan utang, baik utang sewa lahan, padi, dan utang biaya dari masyarakat. Masyarakat melakukan evaluasi di mana ketika masa panen datang sebagian besar akan dipergunakan untuk membayar utang, seperti membayar sewa lahan sebelumnya, membayar sewa padi dari masyarakat, dan sebagainya, sehingga mengurangi perilaku konsumsi pasca panen musim depan.

\section{KESIMPULAN}

Motif masyarakat di Gampong Matang Maneh berperilaku konsumtif pasca panen adalah tersedianya biaya dan keinginan berperilaku konsumtif. Perilaku ini meninggalkan permasalahan seperti tidak sanggup membayar sewa lahan dan kesulitan memenuhi kebutuhan pokok. Kondisi tersebut mendorong sebagian keluarga petani melakukan berbagai upaya guna memenuhi kebutuhan pasca panen seperti melibatkan anggota keluarga dalam bekerja sampingan dan mengutang kebutuhan pokok. Maka sudah sepantasnya para petani merefleksikan kembali perilaku konsumtif mereka agar mampu mengelola hasil panen dengan baik. Hal ini bisa dilakukan dengan membagi hasil panen untuk pengeluaran wajib dan tabungan. Sisa pendapatan barulah digunakan untuk memenuhi keinginan.

\section{DAFTAR PUSTAKA}

Ahmadi, A. (2003). Ilmu Sosial Dasar. Jakarta: Rineka Cipta.

Bakti, I. S., Anismar, \& Amin, K. (2020). Pamer Kemewahan: Kajian Teori Konsumsi Thorstein Veblen. Jurnal Sosiologi USK, 14(1), 81-98.

Basrowi \& Suwandi (2008). Memahami Penelitian Kualitatif. Jakarta: Rineka Cipta.

Damsar \& Indrayani (2009). Pengantar Sosiologi Ekonomi. Jakarta: Kencana.

Emzir (2011). Metode Penelitian Kualitatif: Analisis Data. Jakarta: Rajawali Pers. Haryono (2003). Metodologi Penelitian. Bandung: Pustaka Setia.

44 | Jurnal Ilmu Sosial dan Ilmu Politik Malikussaleh (JSPM) Volume 2 Nomor 1 Tahun 2021 
Ibrohim (2017). Strategi Buruh Nelayan dalam Pemenuhan Kebutuhan Keluarga (Studi pada Pemukiman Gunung Pala Kelurahan Keteguhan Kecamatan Teluk Betung Timur Kota Bandar Lampung). Skripsi. Jurusan Sosiologi Fakultas Ilmu Sosial dan Ilmu Politik Universitas Lampung Bandar Lampung.

Lestari, A. P., \& Muthali'in, M. A. (2018). Perilaku Konsumtif Petani Tembakau: Studi Kasus Panen Raya Tembakau di Desa Gilingsari, Kecamatan Temanggung, Kabupaten Temanggung. Skripsi. Universitas Muhammadiyah Surakarta.

Mangkunegara, A. A. A. P (2002). Perilaku Konsumen. Bandung: Refika Aditama.

Penny, D.H \& Ginting, M. (1984). Pekarangan Petani dan Kemiskinan. Yogyakarta: Pustaka Pelajar.

Rachel, R., \& Rangkuty, R. P. (2020). Konsumerisme dan Gaya Hidup Perempuan di Ruang Sosial: Analisis Budaya Pembedaan Diri di Lingkungan FISIP Unimal. Jurnal Ilmu Sosial dan Ilmu Politik Malikussaleh (JSPM), 1(1), 97-113.

Raharjo (2004). Pengantar Sosiologi Pedesaan dan Pertanian. Yogyakarta: Gadjah Mada University Press.

Rachel, R., \& Rangkuty, R. P. (2020). Konsumerisme dan Gaya Hidup Perempuan di Ruang Sosial: Analisis Budaya Pembedaan Diri di Lingkungan FISIP Unimal. Jurnal Ilmu Sosial dan Ilmu Politik Malikussaleh (JSPM), 1(1), 97-113.

Suharto, E. (2009). Kemiskinan dan Perlindungan Sosial di Indonesia. Bandung: Alfabeta.

Haryanto, S. (2011). Sosiologi Ekonomi. Yogyakarta: Ar-Ruzz Media.

Siti, H. M. (2016). Prilaku Konsumtif Petani Kelapa Sawit Studi: Petani Kelapa Sawit di Desa Sumber Mulya Kecamatan Pelepat Ilir Kabupaten Muara Bungo. Skripsi. Universitas Andalas.

Sudi, M. A., \& Rini, H. S. (2018). Kemiskinan dan Perilaku Konsumtif Masyarakat Petani Cengkeh di Kabupaten Ende, NTT. Solidarity: Journal of Education, Society and Culture, 7(1), 314-328.

Sumartono (2002). Terperangkap dalam Iklan. Bandung: Alfabeta.

Sunarto, I. (2015). Akar Sosial Perilaku Konsumtif Petani Kopi di Desa Garahan Kecamatan Silo Kabupaten Jember. Skripsi. Universitas Negeri Jember.

Tambunan, T. T. H. (2010). Perekonomian Indonesia. Jakarta: Ghalia Indonesia.

Usman, H. \& Akbar, P. S. (2009). Metodologi Penelitian Sosial. Jakarta: Bumi Aksara.

Utami, D. F. V., \& Bashori, K. (2020). Perilaku Konsumtif Petani Tembakau. Skripsi. Universitas Ahmad Dahlan.

45 | Jurnal Ilmu Sosial dan Ilmu Politik Malikussaleh (JSPM) Volume 2 Nomor 1 Tahun 2021 